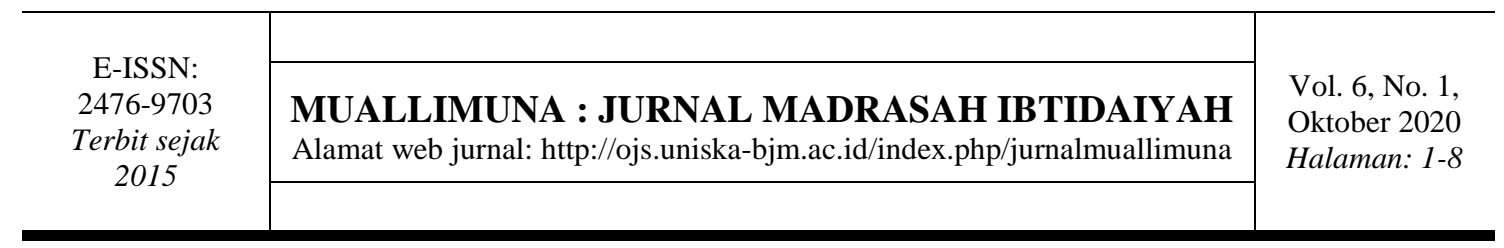

\title{
TEAMS GAMES TOURNAMENT (TGT) DAN DISCOVERY LEARNING (DL) DALAM PEMBELAJARAN MATEMATIKA DI SEKOLAH DASAR
}

\author{
Andi Kaharuddin ${ }^{1}$, Sartika Arifin ${ }^{2}$, Topanus Tulak ${ }^{3}$, Putu Ayu Suyastini ${ }^{4}$ \\ ${ }^{1}$ Universitas Lakidende Unaaha \\ ${ }^{2}$ Universitas Sulawesi Barat \\ ${ }^{3}$ Universitas Kristen Indonesia Toraja \\ ${ }^{4}$ Universitas Tomakaka Mamuju \\ ${ }^{1}$ andikaharuddinunilaki@ gmail.com, ${ }^{2}$ sartikaarifin91@ unsulbar.ac.id, \\ ${ }^{3}$ topan@ukitoraja.ac.id, ${ }^{4}$ ayusuyastini8@gmail.com
}

\begin{abstract}
Abstrak: Penelitian ini mendeskripsikan perbedaan pengaruh dari penerapan TGT dan DL dalam pembelajaran matematika di sekolah dasar. Penelitian ini merupakan Quasi Experiment. Populasi penelitian yaitu siswa kelas VI sekolah dasar dengan sampel yang ditentukan dengan menggunakan teknik Purposive Random Sampling terdiri dari du kelas. Instrumen yang digunakan mengumpulkan data yaitu observasi keaktifan siswa dalam pembelajaran dan tes akhir pembelajaran berupa tes essay. Hasil pengujian secara deskriptif yaitu penerapan TGT berpengaruh positif dibandingkan dengan DL ditinjau berdasarkan hasil belajar dan keaktifan siswa. Berdasarkan pengujian inferensial pada hipotesis penelitian dengan uji $t$ ditemukan $\mathrm{t}_{\text {hitung }}>\alpha$ berarti terdapat perbedaan pengaruh, dimana pengaruh penerapan model TGT lebih tinggi dibandingkan dengan DL. Sehingga, secara umum diinterpretasikan bahwa TGT berpengaruh positif dibandingkan dengan DL terhadap hasil belajar dan keaktifan siswa sekolah dasar.
\end{abstract}

Kata Kunci: Hasil Belajar Siswa; Keaktifan Siswa; TGT; DL

\section{TEAMS GAMES TOURNAMENT (TGT) AND DISCOVERY LEARNING (DL) IN LEARNING MATHEMATICS IN ELEMENTARY SCHOOL}

Abstract: This study describes the different effects of the application of TGT and DL in mathematics learning in elementary schools. This research is a Quasi Experiment. The population of this research is the sixth grade students of elementary school. The sample is determined by using purposive random sampling technique consisting of two classes. The instruments used to collect data were the observation of student activeness in learning and the final test of learning in the form of an essay test. The results of the descriptive test, namely the application of TGT have a positive effect compared to DL in terms of learning outcomes and student activity. Based on inferential testing on the research hypothesis with the $t$ test, it was found that $t_{\text {count }}>\alpha$ means that there is a difference in influence, where the effect of applying the TGT model is higher than that of DL. Thus, it is generally interpreted that TGT has a positive effect compared to DL on learning outcomes and the activeness of elementary school students.

Keywords: Student Learning Outcomes; Student activity; TGT; DL 


\section{PENDAHULUAN}

Mata pelajaran matematika selalu identik dengan angka dan rumus sehingga membuat gairah belajar siswa kurang. Kurangnya gairah belajar siswa dalam pembelajaran matematika membuat siswa tidak paham penjelasan guru yang diberikan. Salah satu penyebab tidak pahamnya siswa dalam pembelajaran matematika yaitu pembelajaran yang diterapkan guru kurang bermakna, hal ini berakibat pada kemampuan kognitif dan psikomotorik siswa (Lowrie \& Jorgensen, 2011; Newton \& Miah, 2017; Ramful \& Lowrie, 2015).

Merujuk kepada kurikulum 2013 dimana guru harus bertugas membuat pembelajaran yang efektif dengan memfokuskan pada peningkatan pengetahuan dan keterampilan. Model kooperatif merupakan tahapan pembelajaran berkelompok dan efektif dalam meningkatkan pemahaman dan keikutsertaan siswa dalam pembelajaran (Kaharuddin, 2018; Umar dkk, 2020). Model kooperatif memiliki ragam variasi misalnya diskusi, eksperimen, demonstrasi dan lain lain (Arjulayana, 2016; Robson, 1945; Sundayana, 2018).

Pembelajaran berkelompok yang berpusat pada siswa dan guru berperan sebagai fasilitator dalam pembelajaran merupakan pengertian dari pembelajaran kooperatif (Hildayatni, Dita, Triwoelandari, Retno, 2018; Kaharuddin \& Magfirah, 2018; Magfirah et al., 2019). Model kooperatif bersifat student centered artinya siswa dalam proses pembelajaran lebih mengedepankan keaktifan siswa, sedangkan guru hanya sebagai fasilitator (Arifin \& Aprisal, 2020; Salo \& Tulak, 2019; Suyastini, 2017).

Model pembelajaran kooperatif terdiri dari kelompok kecil sehingga proses diskusi dengan teman kelompoknya akan maksimal (Dede salim nahdi, 2018; Femi Akinyode \& Hayat Khan, 2016). Model kooperatif yang cocok untuk masalah diatas adalah model TGT dan DL. TGT adalah pembelajaran berkelompok secara heterogen dan beranggotakan 5 sampai 6 orang (Ariani, 2017; Francisco, 2013). TGT merupakan pembelajaran yang digemari siswa karena terdapat games di dalam proses pembelajaran (Kaharuddin, 2013; Putri, Muslimah, Ratman, Mustapa, \& Gani, 2018). Berdasarkan hasil penelitian (Indarti, 2016) menemukan bahwa TGT berhasil meningkatkan kemampuan kognitif siswa. DL merupakan pembelajaran yang membantu siswa berpikir secara mandiri dalam menemukan prinsip baru dari masalah yang diberikan. (Ariani, 2017; Avisca, 2017; Kaharuddin, 2019; Robson, 1945). Kedua model pembelajaran tersebut mampu mengatasi kesulitan siswa dalam belajar, sebab model TGT dan DL berorientasikan kepada kerjasama tim atau kelompok dalam pembelajaran.

Hal tersebut didukung berdasarkan hasil penelitian (Kaharuddin, 2020) tentang penerapan TGT dalam pembelajaran matematika dengan temuan bahwa implementasi TGT meningkatkan kemampuan kerjasama kelompok dan meningkatkn hasil belajar siswa. Hasil penelitian (Haeruman, Rahayu, \& Ambarwati, 2017) tentang DL dalam pembelajaran matematika dengan temuan bahwa karakteristik dari DL mengembangkan kemampuan berpikir kreatif dan gairah siswa dalam belajar.

Hasil temuan tersebut menjadi landasan peneliti menggunakan model TGT dan DL. Sehingga uraian tersebut menjadi dasar peneliti untuk melakukan eksperimentasi dari model TGT dan DL dalam pembelajaran matematika di sekolah dasar di lihat dari keakifan dan hasil belajar di siswa.

\section{METODE}

Jenis penelitian Quasi Experimental. Penelitian Quasi Experimental merupakan penelitian kuantitatif untuk membandingkan dua perlakuan (Hidayat, Nurlaelah, \& 
Dahlan, 2017). Adapun desain penelitian yang digunakan yaitu Nonequivalent Multiple, karen melibatkan dua kelas eksperimen.

Tabel 1. Desain penelitian

\begin{tabular}{cccc}
\hline \multirow{3}{*}{ Random } & Kelas & Perlakuan (Treatment) & Tes akhir (Posttest) \\
\cline { 2 - 4 } & A & $X_{I}$ & $0_{1}$ \\
& B & $X_{2}$ & $0_{2}$ \\
\hline
\end{tabular}

Sumber: (Magfirah et al., 2019)

Adapun populasi penelitian terdiri dari siswa kelas VI sekolah dasar dengan sampel penelitian yaitu siswa kelas VI A dan kelas VI B. Pengumpulan data menggunakan instrumen lembar observasi keaktifan untuk mengamati keterlibatan siswa dalam pembelajaran dan tes akhir atau tes essay untuk melihat dampak dari TGT dan DL setelah pembelajara.

Sedangkan untuk analisis data digunakan analisis secara deskriptif dengan tujuan untuk mendeskripsikan hasil dari penerapan pembelajaran dan inferensial dengan tujuan untuk menguji hipotesis dari perbedaan pengaruh dari penerapan pembelajaran.

\section{HASIL DAN PEMBAHASAN \\ Hasil}

a. Hasil penelitian dari pengujian secara deskriptif pada eksperimen pertama sebagai berikut.

Tabel 2. Rekapitulasi Hasil Belajar Kelas Dari Penerapan TGT

\begin{tabular}{cc}
\hline Kategori & Nilai \\
\hline Nilai Maksimum & 84 \\
Nilai Minimum & 70 \\
Rerata Nilai & 75 \\
Kemiringan & 9 \\
\hline
\end{tabular}

Sumber: Hasil Penelitian

Tabel diatas mengartikan bahwa hasil belajar siswa pada kelas TGT 75 dengan nilai paling tinggi sebesar 84 dan nilai paling rendah sebesar 70, kemiringan data 9 mengartikan bahwa kesamaan nilai siswa mendekati nilai maksimum yaitu 84 . Hal ini dijelaskan pada tabel berikut.

Tabel 3. Rentang Nilai Siswa Dari Penerapan TGT

\begin{tabular}{cc}
\hline Rentang & Jumlah \\
\hline $77-88$ & 7 \\
$65-76$ & 26 \\
\hline
\end{tabular}

Sumber: Hasil Penelitian

Tabel tersebut memperlihatkan jumlah siswa dengan perolehan nilai pada interval sebesar 65-76 atau berada pada kategori sedang berjumlah 26 siswa dan perolehan nilai pada interval 77-88 atau berada pada kategori baik berjumlah 7 siswa. Klasifikasi nilai diatas memperlihatkan bahwa hampir tidak terjadi keberagaman nilai dari hasil belajar siswa. Namun pada dasarnya terdapat beberapa siswa yang memang unggul dalam pembelajaran matematika, baik secara berkelompok atau mandiri.

Secara deskriptif, rata-rata perolehan hasil belajar siswa dari penerapan TGT menunjukkan angka 75 yang mengindikasikan perolehan tersebut lebih tinggi dari KKM yang ditetapkan sekolah. Sehingga dapat di interpretasikan bahwa penerapan TGT berpengaruh positif dilihat dari hasil belajar dan keaktifan siswa. 
b. Hasil penelitian dari pengujian secara deskriptif pada eksperimen pertama sebagai berikut

\begin{tabular}{cc}
\hline Kategori & Nilai \\
\hline Nilai Maksimum & 80 \\
Nilai Minimum & 64 \\
Rerata Nilai & 72 \\
Kemiringan & 4 \\
\hline
\end{tabular}

Sumber: Data Penelitian

Tabel diatas mengartikan bahwa hasil belajar siswa pada kelas DL 72 dengan nilai paling tinggi sebesar 80 dan nilai paling rendah sebesar 64, kemiringan data 4 mengartikan bahwa terjadi keberagaman nilai siswa dan menjauhi nilai maksimum yaitu 80. Hal ini dijelaskan pada tabel berikut.

Tabel 3. Rentang Nilai Siswa Dari Penerapan DL

\begin{tabular}{cc}
\hline Rentang & Jumlah \\
\hline $77-88$ & 6 \\
$65-76$ & 25 \\
$<65$ & 1 \\
\hline
\end{tabular}

Sumber: Hasil Penelitian

Tabel tersebut memperlihatkan jumlah siswa dengan perolehan nilai pada interval kurang dari 65 berada pada kategori kurang berjumlah 1 siswa, perolehan nilai pada interval sebesar 65-76 atau berada pada kategori sedang berjumlah 25 siswa dan perolehan nilai pada interval 77-88 atau berada pada kategori baik berjumlah 6 siswa. Terjadinya keberagaman nilai ini terjadi karena aktivitas siswa dalam pembelajaran secara berkelompok. Namun pada dasarnya terdapat beberapa siswa yang memang unggul dalam pembelajaran matematika, baik secara berkelompok atau secara individu.

Secara deskriptif, rata-rata perolehan nilai hasil belajar siswa dari penerapan DL menunjukkan angka 72 yang mengindikasikan perolehan tersebut lebih dan mendekati nilai kriteria ketuntasan minimal yang ditetapkan disekolah. Sehingga dapat di interpretasikan bahwa penerapan DL berpengaruh terhadap nilai hasil belajar dan keaktifan siswa

c. Perbedaan pengaruh model TGT dan DL.

Pengujian secara deskriptif dilakukan untuk melihat perbedaan pengaruh dari penerapan model TGT dan DL dapat dilihat pada grafik 1 berikut ini.

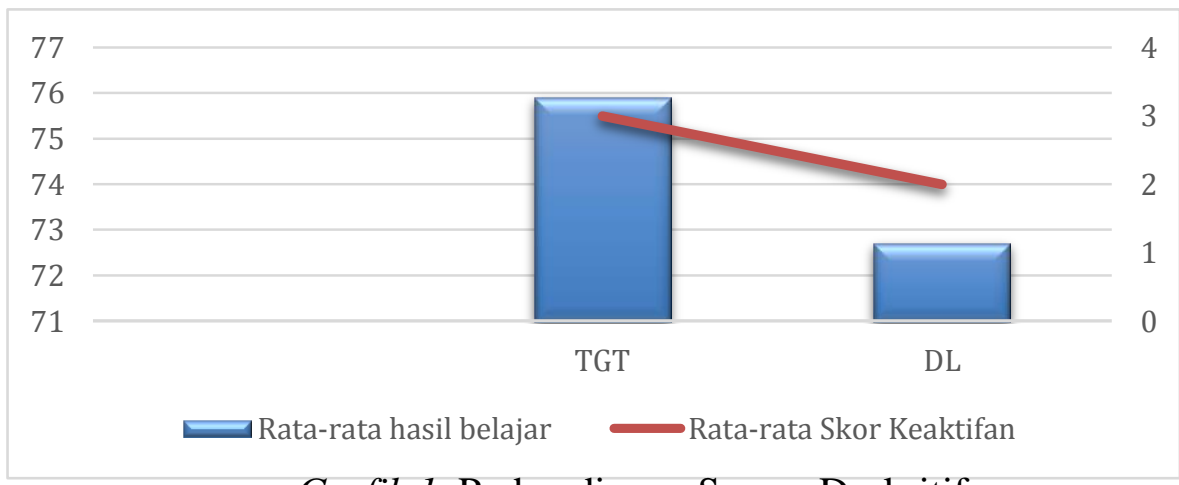

Grafik 1. Perbandingan Secara Deskritif

Dari grafik tersebut terlihat bahwa perbandingan perolehan rerata hasil belajar siswa dari penerapan TGT lebih besar dari pada DL. Rata-rata skor keaktifan siswa dalam pembelajaran TGT lebih aktif dari pada DL, ini terlihat skor keaktifan siswa 
dalam pembelajaran TGT berada pada kategori cenderung positif 3 dan DL cenderung negatif. Hasil tersebut mengindikasikan bahwa penerapan TGT lebih berpengaruh dibandingkan dengan DL dalam pembelajaran matematika di sekolah dasar dilihat dari hasil belajar dan keaktifan siswa.

Selanjutnya hasil pengujian hipotesis dengan uji inferensial diperoleh nilai $t_{\text {hitung }}>$ $\alpha$ menerima $\mathrm{H} 1$, ini berarti terdapat perbedaan yang signifikan dari penerapan TGT dan DL dalam pembelajaran matematika di sekolah dasar, dimana secara spesifik model TGT lebih berpengaruh positif dibandingkan dengan DL dalam pembelajaran matematika.

\section{Pembahasan}

Penerapan pembelajaran pada eksperimen pertama berjalan dengan sangat baik, siswa secara rata-rata melebihi kriteria ketuntasan minimal. Namun pencapaian nilai hasil belajar siswa tersebut belum merata, hal ini dikarenakan didalam proses pembelajaran dengan penerapan TGT, siswa dominan bermain dari pada belajar, ini terlihat dari proses bekerja secara berkelompok, siswa tampak menikmati permainan dalam pembelajaran, siswa yang cerdas terlihat menegur dan mengingatkan teman kelompoknya akan pentingnya pemahaman dari materi yang diberikan. Sehingga pada dasarnya akan terlihat pada hasil pembahasan terdapat beberapa siswa yang memperoleh nilai berkategori tinggi. Aktivitas siswa dari penerapan TGT positif, hal tersebut terlihat dari hasil observasi guru dimana siswa mampu bekerja sama dan terlibat dalam penugasan secara berkelompok.

Penerapan pembelajaran pada eksperimen kedua berjalan dengan baik, namun belum mencapai kategori sangat baik, hasil belajar siswa secara rata-rata melebihi kriteria ketuntasan minimal. Akan tetapi terjadi keberagaman nilai, hal ini dikarenakan didalam proses pembelajaran DL, siswa sekolah dasar belum mampu berpikir secara mandiri, siswa sekolah dasar masih membutuhkan arahan dari guru sehingga keterampilan dan keaktifan siswa belum maksimal. Adapun untuk keaktifan siswa dari penerapan model pembelajaran DL cenderung negatif, hal tersebut terlihat dari hasil observasi guru dimana siswa mampu tampak kebingungan dalam menerima materi dan mengerjakan soal.

Setelah dilakukan pengujian secara deskriptif diperoleh kesimpulan bahwa hasil belajar siswa dari penerapan TGT lebih tinggi dari DL, hal ini mengartikan bahwa dari penerapan TGT jauh lebih berhasil dibandingkan dengan model DL. Setelah dilakukan wawancara kepada guru ternyata diperoleh informasi baru bahwa pada dasarnya siswa kelas IV di sekolah tersebut senang dengan pembelajaran yang dikaitkan dengan konsep bermain. Karena membuat siswa mampu mengeksplor pemahamannya secara sempurna. Hal ini sejalan dengan teori piaget (Ibda, 2015) bahwa anak pada rentang umur 12 lebih cenderung senang bermain. Hasil penelitian (Suratno, Utami, \& Hamid, 2015) mengatakan bahwa siswa sekolah dasar masih sangat senang dengan bermain.

Selanjutnya dilakukan uji inferensial dari penerapan model TGT dan DL dan diperoleh hasil bahwa $\mathrm{H} 1$ diterima yang berarti terdapat perbedaan pengaruh dari penerapan model TGT dan DL, secara spesifik terlihat bahwa model TGT lebih berpengaruh positif dibandingkan DL dalam pembelajran matematika. Kajian teori dan hasil penelitian tersebut peneliti dapat menyimpulkan bahwa penerapan TGT lebih baik dari DL dilihat dari hasil belajar, karena proses TGT membuat siswa belajar secara bermain, sedangkan DL lebih kepada belajar secara mandiri. Selanjutnya untuk rata-rata skor keaktifan siswa berbanding lurus dengan nilai hasil belajar. Hal yang sama juga 
disampaikan oleh (Fadjrin, 2018) bahwa keaktifan siswa memiliki hubungan positif terhadap hasil belajar siswa.

Adapun novelty dalam penelitian ini yaitu jika keaktifan siswa positif maka hasil belajarnyapun meningkat, sebaliknya jika keaktifan siswa negatif maka hasil belajaranyapun menurun. Berdasarkan uraian dari hasil dan pembahasaan diatas maka secara deskriptif dan inferensial dapat disimpulkan bahwa TGT berpengaruh positif dibandingkan dengan DL dalam pembelajran matematika di sekolah dasar dilihat dari hasil belajar dan keaktifan siswa.

\section{PENUTUP}

Berdasarkan penjelasan sebelumnya maka diperoleh kesimpulan bahwa pengaruh dari penerapan model TGT lebih besar dari pada DL dalam pembelajaran matematika siswa di sekolah dasar dilihat dari hasil belajar dan keaktifan siswa.

\section{UCAPAN TERIMA KASIH}

Ucapan terima kasih disampaikan kepada semua pihak yang ikut membantu dalam proses penelitian ini, baik dari segi pengumpulan data, materi dan pelaporan.

\section{DAFTAR PUSTAKA}

Ariani, D. N. (2017). Strategi Peningkatan Kemampuan Komunikasi Matematis Siswa SD/MI Informasi. Muallimuna: Jurnal Madrasah Ibtidaiyah, 3(1), 96-107. https://doi.org/http://dx.doi.org/10.31602/muallimuna.v3i1.958

Arifin, S., \& Aprisal. (2020). J urnal Pendidikan Matematika. 11(1), 89-98.

Arjulayana, A. (2016). Indonesian Students' Learning Style in English Speaking Skill. Jurnal Dinamika UMT, 1(2), 1. https://doi.org/10.31000/dinamika.v1i2.574

Avisca, K. (2017). Penggunaan model pembelajaran kooperatif tipe make a match berbantuan media speaking card sebagai upaya peningkatan hasil belajar. FKIP Uiversitas Kristen Satya Wacana, 33(1), 56-63.

Dede salim nahdi. (2018). Efektivitas Pendekatan Brainstorming Teknik Round-Robin Dalam Meningkatkan Kemampuan Komunikasi Matematis Siswa Sekolah Dasar. Muallimuna: Jurnal Madrasah Ibtidaiyah, 5(1), 57-64. https://doi.org/https://dx.doi.org/10.31602/muallimuna.v5i1.2253

Fadjrin, N. N. (2018). Hubungan Keaktifan Belajar di Sekolah terhadap Hasil Belajar Matematika Siswa Kelas VIII. Jurnal Ilmiah Mathgram Program Studi Matematika, 2(01), 1-8. Retrieved from https://ejournal.unugha.ac.id/index.php/mthg/article/view/169

Femi Akinyode, B., \& Hayat Khan, T. (2016). Students' Learning Style among Planning Students in Nigeria using Kolb's Learning Style Inventory. Indian Journal of Science and Technology, 9(47), 1-13. https://doi.org/10.17485/ijst/2015/v8i1/107129

Francisco, A. R. L. (2013). Perbandingan Hasil Belajar Siswa Yang Diajar Dengan Model Pembelajaran Kooperatif Tipe Teams Games Tournament (TGT) Dengan Tipe Students Teams Achievement Division (STAD) Pada Materi Bangun Datar Persegi. Journal of Chemical Information and Modeling, 53(9), 1689-1699. https://doi.org/10.1017/CBO9781107415324.004

Hidayat, D., Nurlaelah, E., \& Dahlan, J. A. (2017). Rigorous Mathematical Thinking Approach to Enhance Students' Mathematical Creative and Critical Thinking 
Abilities. Journal of Physics: Conference Series, 895(1), 1-7. https://doi.org/10.1088/1742-6596/895/1/012087

Ibda, F. (2015). Perkembangan Kognitif: Teori Jean Piaget. Intelektualita, 3(1), 242904. Indarti, C. (2016). Pembelajaran Ips Melalui Model Cooperative Learning Dengan Teknik Make A Match Untuk Meningkatkan Hasil Belajar Siswa Kelas Iv Sdn Tiron 02 Teaching Social Science through Cooperative Learning Model with Make a Match Technique to Improve Learning Achievem. Jurnal Studi Sosial, 1(1), 52-59.

Haeruman, L. D., Rahayu, W., \& Ambarwati, L. (2017). Pengaruh model Discovery Learning terhadap peningkatan kemampuan berpikir kritis matematis dan selfconfidence ditinjau dari kemampuan awal matematis siswa SMA di Bogor Timur. JPPM (Jurnal Penelitian Dan Pembelajaran Matematika), 10(2).

Kaharuddin, A. (2013). Effectiveness Comparative Of Scientific Approach ELPSA And Open-Ended Setting Cooperative STAD Types Of Mathematics Learning At VII Class SMP Negeri Of A Accreditation In Makassar. Daya Matematis: Jurnal Inovasi Pendidikan Matematika, 1(1), 29-44.

Kaharuddin, A. (2018). Keefektifan Model Make A Match dalam Pembelajaran Matematika Siswa Kelas VI Sekolah Dasar di Kecamatan Marioriwawo. Madrasah: Jurnal Pendidikan dan Pembelajaran Dasar, 11(1), 13-23.

Kaharuddin, A. (2019). Effect of Problem Based Learning Model on Mathematical Learning Outcomes of 6th Grade Students of Elementary School Accredited B in Kendari City. International Journal of Trends in Mathematics Education Research, 1(2).

Kaharuddin, A. Komparasi Model Kooperatif Tipe Jigsaw Dengan Team-GamesTournament Dalam Pembelajaran Matematika Siswa Sekolah Dasar. Metodik Didaktik: Jurnal Pendidikan Ke-SD-an, 15(2).

Kaharuddin, A., \& Magfirah, I. (2018). Perbandingan Keefektifan Model Tps Stad pada Pembelajaran Matematika Kelas VI Sekolah Dasar Negeri di Kabupaten Soppeng. Taman Cendekia: Jurnal Pendidikan Ke-SD-an, 2(2), 223-230.

Lowrie, T., \& Jorgensen, R. (2011). Gender differences in students' mathematics game playing. Computers and Education, 57(4), 2244-2248. https://doi.org/10.1016/j.compedu.2011.06.010

Magfirah, I., Kaharuddin, A., \& Wangse, F. (2015). Efektifitas Model Pembelajaran Kooperatif Tipe Think Pair Share (Tps) Dengan Pendekatan Open-Ended Dalam Pembelajaran Matematika Materi Segi Empat Siswa Kelas Viii Smpn 14 Buru. Matematika, 104.

Newton, P. M., \& Miah, M. (2017). Evidence-based higher education - Is the learning styles "myth" important? Frontiers in Psychology, 8(MAR), 1-9. https://doi.org/10.3389/fpsyg.2017.00444

Putri, E. P. K., Muslimah, -, Ratman, -, Mustapa, K., \& Gani, A. (2018). Effect of Cooperative Make a Match Learning Model on Student's Learning Outcomes on Electrolyte and Non-Electrolyte Solutions Topics. Atlantis Press, 174(Ice 2017), 134-137. https://doi.org/10.2991/ice-17.2018.31

Ramful, A., \& Lowrie, T. (2015). Spatial Visualisation and Cognitive Style : How Do Gender Differences Play Out? Mathematics Education in the Margins, 508-515. Canberra: Australia : Mathematics Education Research Group of Australasia. 
Robson, A. (1945). Reviewed Work: How to Solve It by G. Pólya. The Mathematical Gazette, Vol. 30, p. 181. https://doi.org/10.2307/3609122

Salo, E. S., \& Tulak, T. (2019). Penerapan Model Pembelajaran Kooperatif Tipe STAD Untuk Meningkatkan Keaktifan Belajar Matematika Siswa Kelas IV SDN 5 Tikala Kabupaten Toraja Utara. Elementary Journal, 2(1), 1-15.

Sundayana, R. (2018). Kaitan antara Gaya Belajar, Kemandirian Belajar, dan Kemampuan Pemecahan Masalah Siswa SMP dalam Pelajaran Matematika. Mosharafa: Jurnal Pendidikan Matematika, 5(2), 75-84. https://doi.org/10.31980/mosharafa.v5i2.262

Suratno, J., Utami, N. W., \& Hamid, H. (2015). Delta-Pi:Jurnal Matematika dan Pendidikan Matematika. 4(1), 80-91.

Suyastini, P. A. (2017). Comparison of the Effectiveness of Project Based Learning Model and Problem Based Learning in Mathematics Learning At Public Junior High Schools With a Accreditation in Makassar City. Jurnal Daya Matematis, 5(2), 61. https://doi.org/10.26858/jds.v5i2.3339

Umar, U., Kaharuddin, A., Fauzi, A., Widodo, A., Radiusman, R., \& Erfan, M. (2020, August). A Comparative Study on Critical Thinking of Mathematical Problem Solving Using Problem Based Learning and Direct Intruction. In 1st Annual Conference on Education and Social Sciences (ACCESS 2019) (pp. 314-316). Atlantis Press. 